\title{
Type 1 Diabetes and Physical Activity in Children and Adolescents
}

\author{
Leclair $\mathrm{E}^{1 *}$, de Kerdanet $\mathbf{M}^{2}$, Riddell $\mathbf{M}^{1}$ and Heyman $\mathrm{E}^{3}$
}

${ }^{1}$ School of Kinesiology and Health Science, York University, Canada

${ }^{2}$ Department of Pediatric Endocrinology, University Hospital of Rennes, France

${ }^{3}$ Univ Lille Nord de France, EA 4488 Activité physique, Muscle, Santé, Lille, France

\begin{abstract}
The diagnosis of type 1 diabetes (T1D) often occurs in childhood; age and maturation of that patient come with elevated risk of developing microvacular complications and cardiac disease. Insulin treatment, diet control and physical activity are incorporated in T1D treatment, and childhood should be a time at which good diabetes control habits should be developed. Exercise clearly offers many health and psychological benefits, improves body composition, insulin sensitivity, glycemic control and quality of life. Unfortunately, T1D adolescents often do not achieve the recommended physical activity level and are sometimes less active than healthy adolescents. A clear statement about expected beneficial effects is required in order to encourage and to provide opportunities for engaging in physical activity since childhood fosters the maintenance of an active lifestyle in adulthood. This review highlights the beneficial effects of physical activity in T1D children and adolescents and provides some guidance on how physical activity should be managed in this patient population.
\end{abstract}

Keywords: Exercise; Type 1 diabetes; Children; Adolescents; Adherence; Barriers; Exercise intensity

Abbreviations: PA: Physical Activity; ATP: Adenosine Triphosphate; T1D: Type 1 Diabetes or Type 1 Diabetes Patient; GLUT 4: Glucose Transporters; HbA 1 : Alc Glycated hemoglobin; HDL-C: High-Density-Lipoprotein-Cholesterol; LDL-C: Low Density Lipoprotein-Cholesterol; $\mathrm{PWC}_{170}$ : Physical Working Capacity 170; $\mathrm{VO}_{2}$ : Oxygen consumption

\section{Introduction}

Type 1 diabetes (T1D) is a form of diabetes that results from autoimmune destruction of insulin-producing beta cells of the pancreas. This insulin deficiency once quickly caused death in children, but technological advances in insulin therapy and diabetes management tools now allow for a near full life expectancy with dramatically improved patient quality of life. Nonetheless, poor diabetes management can lead to diabetes-related complications and childhood should be a time in which good diabetes control habits should be developed. Since the diagnosis of type 1 diabetes (T1D) often occurs in childhood, age and maturation of that patient brings elevated risk of developing microvacular (diabetic retinopathy, nephropathy, and neuropathy) and macrovascular complications. Therefore, childhood represents a very good timeframe to focus on the prevention of microand macrovascular disease through good diabetes management.

Type 1 diabetes treatment is based on exogenous insulin injection, diet control and regular physical activity. A basal insulin concentration is needed throughout the day, but insulin boluses are also required at mealtimes and for corrections for hyperglycemia. However, other parameters, such as physical activity, illness and stress levels have to be constantly monitored to determine the appropriate insulin dosage. It is generally well accepted that regular activity along with a good diet are helpful in maintaining glycemic control, since very sedentary behavior is associated with poor control [1].

Diet recommendations are relatively straight forward for children and adolescents with T1D, and are similar to the general dietary guidelines for healthy children [2]. When respected, this helps to avoid unbalanced and irregular carbohydrate intake. The aim of regular physical activity for youth with type 1 diabetes is to improve quality of life and to enhance both short-term and long-term health. Due to the possibility of worsening metabolic control during exercise (resulting in either hypoglycemia or hyperglycemia), guidelines regarding metabolic control, blood glucose monitoring and food intake for physical activity must be followed. Some review papers have focused on glycemic variations with exercise and on practical considerations for the clinical management of type 1 diabetes in athletic youth [1,3-7]. Other reviews previously presented exercise training induced benefits on glycemic control in both adulthood and childhood $[8,9]$ but not on different other important health related parameters. The purpose of this review is to focus on the short- and long-term effects of different training models in youth with T1D and to understand which mechanisms are involved. This review will also focus on physical activity rate in young T1D and analyze what would limit their adherence, in order to improve its promotion.

\section{Beneficial Effects of a Regular Physical Activity}

In T1D management, physical activity, glycemic control, insulin treatment and diet control represent the three cornerstones of care. Physical activity by itself induces health-related beneficial effects and improves patient quality of life.

\section{Beneficial effects of regular exercise in young patients with T1D}

A number of studies of TD1 children or adolescent have shown that pure endurance or mixed (endurance and strength exercise) training have beneficial effects in type 1 diabetes. After 3 to 9 months, training has beneficial effects on quality of life (assessed using a questionnaire) [10-13], endurance capacity (4 to $34 \%$ improvement) [11,14-24],

${ }^{*}$ Corresponding author: Erwan Leclair, Department of Kinesiology and Health Science, York University, 4700 Keele Street, Toronto, Ontario M3J 1P3, Canada, E-mail: leclair.erwan@gmail.com

Received May 10, 2013; Accepted June 17, 2013; Published June 22, 2013

Citation: Leclair E, de Kerdanet M, Riddell M, Heyman E (2013) Type 1 Diabetes and Physical Activity in Children and Adolescents. J Diabetes Metab S10: 004. doi:10.4172/2155-6156.S10-004

Copyright: @ 2013 Leclair E, et al. This is an open-access article distributed under the terms of the Creative Commons Attribution License, which permits unrestricted use, distribution, and reproduction in any medium, provided the original author and source are credited. 
body composition - fat to muscle mass ratio [10,15,16,21,22,25], lipid profile - fraction of 'good' (HDL-C) and 'bad' cholesterol (LDL-C) $[10,21,26,27]$, tissue insulin sensitivity - insulin receptor efficiency [22], and finally, but not universally observed, glycemic control (as reflected by improvement of long term indicator $\mathrm{HbA}_{1 \mathrm{c}}$, or short and middle term indicators such as fructosamine, glycemia/glycosuria) [16,18,20,21,26-30] (Table 1 data included as supplementary). It is worth noting that lipid profile and fructosamine improvement can be observed after only 2 weeks of intensive physical activity in youth with T1D [27].

Importantly, some studies in young patients with T1D report training-induced improvement in bone mineral density [25], vascular function (vasomotricity) [14] and antioxidant capacity [31].

These results from longitudinal studies are in accordance with cross-sectional studies, which underline significant correlations between different health indicators and the amount of physical activity performed as assessed by accelerometer and/or questionnaires [32-44].

However, since the beneficial effects of exercise training are not systematically observed (Table 1 data included as supplementary), it seems relevant to examine further the underlying mechanisms involved in order to adapt and optimize the training prescription.

Physical fitness improvement and underlying mechanisms: All studies except two, show that aerobic fitness, evaluated with maximal oxygen uptake $\left(\mathrm{VO}_{2} \mathrm{max}\right.$ ) or $\mathrm{PWC}_{170}$ (power output corresponding to $170 \mathrm{bpm}$ during an incremental test), is improved when the training lasts for at least 3 months and is supervised $[28,45]$. The aerobic capacity improvement could be linked to different parameters like heart volume [19] and muscle mass improvement [10] following training. The increase of muscle aerobic enzyme maximal activity could also be involved, but to date, data are just available in the adult T1D population [46-48].

Insulin sensitivity and underlying mechanisms: Only a few papers have focused on the effects of regular exercise on tissue insulin sensitivity in T1D children, but results are encouraging $[22,24]$. Training-induced improvements in insulin sensitivity may be particularly important in children and adolescents, since puberty is known to increase insulin resistance, especially in girls $[49,50]$. The stimulating effect of insulin on glucose metabolism, measured during hyperinsulinemic euglycemic clamp, is reduced by 33 to $42 \%$ in T1D adolescent compared to prepubescent and adult T1D [49]. It is also worth noting that in T1D, 2 weeks of intense activity decreases circulating ghrelin levels [51], while more prolonged training (6 months) attenuates the puberty induced increase in leptin levels [10]. Ghrelin and leptin are both insulin resistance indicators/factors.

There are likely multiple underlying mechanisms for training induced improvements in insulin sensitivity in youth with T1D. A first explanation could be the training-induced improvement in body composition. The training-induced lean mass gain observed in youth with T1D $[10,21,22,25]$ is likely representative of muscle mass gain, which may be linked to improvement in peripheral insulin sensitivity. Indeed, skeletal muscle represents the main insulin stimulated glucose utilization site, even at rest (consumption of $54.4 \mathrm{~kJ} / \mathrm{kg} / \mathrm{j}$ vs. $18.8 \mathrm{~kJ} /$ $\mathrm{kg} / \mathrm{j}$ for adipose tissue) [52-54]. In addition, muscle is quantitatively the main tissue involved in lipid metabolism [55,56]. Muscle energy expenditure during each training session could lead to fat mass decrease [57], that has already been observed in a few studies of youth with T1D [15,21] (Table 1 data included as supplementary). The fat mass decrease could induce improvement in insulin resistance since when adipose tissue mass is in excess, it secretes more molecules (adipocytokines) like leptin, that increases insulin resistance [58]. A 6-month combined training (aerobic and muscle strength) was able to limit fat mass increase, and also leptin levels, in T1D adolescents who were in their later stages of puberty [10]. In this context, it seems reasonable to combine different training models that would at the same time, also help to avoid monotony and keep young T1D patients motivated. As such, the exercise prescription could be as follows:

Muscle strength training activities [10,21], such as weight bearing, weight activities, like jumping, push-up and sit-ups, step climbing machines, rope climbing, and rock climbing [10,25] are all favorable for muscle mass gain [59], which should promote increased insulin sensitivity.

Aerobic exercise activities like running or swimming [15], which promote increased energy expenditure, increase aerobic fitness and increase lipid oxidation - they can be planed as continuous and moderate intensity (example : $30 \mathrm{~min}$ at $50 \% \mathrm{VO}_{2}$ peak), or as high intensity intermittent exercise (example : $30 \mathrm{sec}$ at $100 \% \mathrm{VO}_{2}$ peak/30sec recovery). This kind of intermittent activity has been shown to improve insulin sensitivity in healthy subjects [60]. Moreover, intermittent exercise is comparable to continuous exercise (at the same total mechanic work) according to the total energy expenditure during exercise and lipid oxidation level during recovery [61]. Intermittent exercise also tends to represent the type of activities that children prefer according to Bailey et al. [62].

Training induced structural and functional skeletal muscle adaptations could be responsible for the enhancement of peripheral insulin sensitivity. For example, it has been shown in healthy adults and in adults with Type 2 diabetes that physical training improves glucose delivery to muscle via an enhanced muscle vascularization (increased muscle capillaries number, and increased local blood flow) [63]. It also has been shown that maximal capacity for glucose utilization is improved via increased glucose transporter (GLUT4) number [63] and/or maximal activity of the enzymes involved in blood glucose catabolism (i.e. hexokinase), or muscle glucose disposal (i.e. glycogen synthase) [63]. In T1D adult, the same improvement is observed for muscle capillarization [46,47] and maximal activity of enzymes involved in aerobic glucose disposal (citrate synthase) $[46,48]$ (Succinate dehydrogenase) $[47,48]$ after 2 to 4 months of aerobic training.

Glycemic control improvement and underlying mechanisms: In general, regular exercise improves insulin sensitivity in youth with T1D. However, it should be noted that the putative improvement in exercise-induced peripheral insulin sensitivity in young patients with T1D $[22,24]$ is not always coincidental with the improvement of the following parameters (usually linked to improved insulin sensitivity) : daily insulin dose decrease $[10,11,22,24,51,64]$ and glycemic control improvement [10-12,17,22-24,31,51,64,65] (Table 1 data included as supplementary). This could be linked to a difficult management of exercise glycemic variations influenced by multiple factors (delay between last meal and insulin injection, insulin absorption, initial glycemia, time of the day, etc.) [1]. Because of these glycemic variations and the fear of hypoglycemia, patients might consume carbohydrates in excess [66] or they may decrease their insulin dose far too aggressively, thereby eliminating the potential improvements in glucose disposal. This can explain why several studies show significant decrements in total daily insulin dose but no improvement in glycemic control $[13,45]$. This behavior might induce hyperglycemia, and hence even impair glycemic control [17,45]. 
On the contrary, when young patients with T1D benefit from recommendations about diet control, insulin therapy and glucose monitoring in addition to the training program, glycemic control $\left(\mathrm{HbA}_{1 \mathrm{c}}\right.$ or fructosamine) can significantly improve [20] and this even after only two weeks of high intensity physical activity $[27,29]$.

The effects of chronic exercise on glycemic control in patients (age from 8 to 48 years old) with T1D have been recently studied in a meta-analysis by Tonoli [8]. In prepubescent children (average age 12.1 years old) [17,65], this meta-analysis does not highlight any glycemic improvement with aerobic training. However, chronic aerobic exercise significantly decreased $\mathrm{HbA}_{1 c}$ levels in a group of 61 adolescents (average age 13.8 years old) with a poor glycemic control (from studies : [16,20,28-30]). Combined training (aerobic and muscle strength exercise) (based on $[10,13,21,67]$ ) slightly decreased $\mathrm{HbA}_{1}$ levels (Best improvement: from 7.72 to 6.76) in T1D adolescents (average age 17.2 years old). When both young and adult T1D results were analyzed together, beneficial effects were found: exercise traininginduced glycemic control improvement could be observed when training lasted at least 3 months, including 1 to 3 sessions a week, and when diet control and insulin therapy recommendations were added. Glycemic control improved more after training when initial glycemic control was poor $\left(\mathrm{HbA}_{1 \mathrm{c}} \geq 8 \%\right)$.

Lipid profile improvement and underlying mechanisms: According to the studies in table 1 (Data included as supplementary), lipid profile (especially HDL-C / LDL-C ratio) improves more when training session frequency is increased [26], and when the glycemic control is improved at the same time [21,26,27]. When glycemic control is not improved with training, most studies [10,24,31,45,64], except one [68], do not detect any improvement in LDL-C and/or HDL-C. This result is in accordance with the fact that glycemic control and lipid profile are often highly correlated health parameters in T1D [69-74]. The link between lipid profile and glycemic control, and their parallel improvement induced by exercise training, could be explained by the negative impact of insulin deficiency and excessive glycosylation (observed in case of high $\mathrm{HbA}_{1}$ level) on LDL degradation and removal, hence increasing LDL-C levels [75]. Moreover, lipolysis, also accentuated in case of insulin deficiency and insulin resistance, increases free fatty acid and serum glycerol, which could in turn impair glucose metabolism through the Randle cycle [2].

Training induced beneficial effects on lipid profile and glycemic control, could eventually diminish the chances to develop vascular complications. According to Kriska et al. [76], an improved spontaneous physical activity between 14 and 17 years old lowers nephropathy and neuropathy prevalence in adults T1D.

Finally, and perhaps most importantly, physical exercise is also very important for enhancing the quality of life (QOL) in young T1D [1013], especially during psychological instable periods such as puberty.

\section{Adherence and limits to physical activity in young patients with T1D}

Because of the numerous beneficial effects on physical and psychological health (see section 1), exercise is clearly highly recommended in young T1D. Nonetheless, some evidence exists to suggest that participation in exercise and physical activity is often suboptimal.

\section{Physical activity engagement in young patients with T1D}

As shown in table 2, T1D adolescents often do not achieve the recommended physical activity level (often set at $60 \mathrm{~min}$ a day and including moderate to high intensity exercise) and they are often even less active than their non-diabetic healthy peers. This relative inactivity is especially observed in girls and this gender difference is observed in early childhood (i.e. as early as 6-7 years of age [77].

In order to motivate patients who are not involved in physical activity, it is important to know why they choose not to participate in regular activity. A study by Faulkner et al. [12] showed that adolescents with T1D exercising more than 10 min a day don't have any negative or limiting feelings about physical activity (PA) (evaluated with Diabetes Social Support Questionnaire-Family Version, DSSQ-Family). Also, the frequency of exercise sessions, longer than $30 \mathrm{~min}$, is correlated to the feeling of important family support [12,78].

A Canadian investigation from Quebec [79] conducted in 100 T1D adults showed that the 4 main limitations for exercising were : fear of hypoglycemia (the highest barrier), work schedule, loss of control over diabetes and low levels of fitness. However, further studies are needed in large samples of children and adolescents with T1D in order to determine what are the main barriers to physical activity participation in this age group. It is possible that, like in adults, a fear of hypoglycemia and low levels of fitness could represent strong barriers.

\section{Two possible barriers to physical activity in youth with T1D: Exercise-induced hypoglycemia and low fitness levels}

Exercise induced hypoglycemia: Most studies about T1D children and adolescents acknowledge the fact that blood glucose levels decrease during moderate intensity continuous exercise (Table 3). Thus, the fear of hypoglycemia could become a major barrier to physical activity participation in this population. However, when T1D children and adolescents stop their insulin pump basal rate altogether [80], or decrease it by $20 \%$ [81] or $50 \%$ [82] during a moderate intensity continuous exercise, hypoglycemia occurrence risk is lowered during the activity [80], but also during the following night [81]. Importantly, if exercise is performed at the same time as peak insulin (fast acting) action or during insulin bolus action, it is recommended to anticipate the activity and to decrease the insulin dose at the meal before exercise from 30 to $100 \%$, depending on the duration and intensity of the activity $[83,84]$. However, the reduction in basal insulin delivery could also enhance hyperglycemia events in early recovery [80] and during the subsequent evening [81] (Table 3). The timing of basal insulin reduction should be about 60-90 minutes before the start of exercise to allow for circulating insulin levels to already be diminished by the time exercise starts [85]

An alternative to insulin modification, to prevent hypoglycemia, is to vary the type of exercise performed (duration, intensity, modality). It has been shown in T1D adults that the addition of sprints before (45 min muscle strength exercise [86]), during (sprint: 4 sec every 2 min [87,88], or $15 \mathrm{sec}$ every $2 \mathrm{~min}[89])$ or after (10 sec once [90]) moderate intensity endurance exercise ( 40 to $60 \%$ of maximal aerobic power during 20 to $45 \mathrm{~min}$ ) attenuates the drop in blood glucose, or the occurrence of subsequent hypoglycemia, compared to when just moderate intensity exercise is performed. In young patients with T1D, only one study compared the effects of high intensity intermittent exercise (6 times $3 \mathrm{~min}$ at $70 \%$ of maximal aerobic power with $1.5 \mathrm{~min}$ recovery) with moderate intensity exercise (60 min at $40 \%$ of maximal aerobic power) [91]. The authors found that the former exercise protects against late-onset hypoglycemia (Table 3 ). This positive effect of adding sprints or high-intensity exercise might be the result of increased stress hormones secreted (epinephrine or cortisol) [91]. 
Citation: Leclair E, de Kerdanet M, Riddell M, Heyman E (2013) Type 1 Diabetes and Physical Activity in Children and Adolescents. J Diabetes Metab S10: 004. doi:10.4172/2155-6156.S10-004

Page 4 of 10

\begin{tabular}{|c|c|c|c|c|}
\hline Authors & T1D subjects & $\begin{array}{l}\text { Healthy } \\
\text { population } \\
\text { comparison }\end{array}$ & Physical level evaluation methods & Physical activity level of young T1D \\
\hline [101] & $6-20$ yo & Yes & $\begin{array}{l}\text { Physical activity evaluation by the } \\
\text { mother according to } 3 \text { levels }\end{array}$ & $\begin{array}{l}\text { Physical activity decrease with age, more important in T1D compared to } \\
\text { healthy subjects. }\end{array}$ \\
\hline [102] & $\begin{array}{l}\text { Children and } \\
\text { adolescents }\end{array}$ & No & Behaviour questionnaire & $\begin{array}{l}\text { Behaviour with physical activity more negative in T1D adolescents } \\
\text { compared to T1D children. }\end{array}$ \\
\hline [103] & $10-15$ yo & Yes & $\begin{array}{l}\text { Descriptive questionnaire. Not } \\
\text { quantitative }\end{array}$ & $\begin{array}{l}\text { T1D are more involved in light intensity activities compared to control who } \\
\text { prefer competition. }\end{array}$ \\
\hline [104] & $6-18$ yo & Yes & $\begin{array}{l}\text { Descriptive questionnaire. Not } \\
\text { quantitative }\end{array}$ & $\begin{array}{l}\text { T1D have better adherence to physical activity in gym compared to } \\
\text { healthy subjects ( } 40 \% \text { vs. } 27 \%) \text {. }\end{array}$ \\
\hline [11] & & & & $\begin{array}{l}\text { Patients with the best adherence to training program are the youngest, } \\
\text { with a better glycemic control. }\end{array}$ \\
\hline [105] & o 10.2-16.5yo & Yes & $\begin{array}{l}\text { Physical activity evaluation by the } \\
\text { parents according to } 5 \text { levels }\end{array}$ & No significant difference compared to healthy controls. \\
\hline [106] & $\mathrm{N}=142 ; 6-18$ yo & $\begin{array}{l}\text { Yes }(n=97 \\
\text { BMI matched) }\end{array}$ & $\begin{array}{l}\text { No indication about the Questionnaire } \\
\text { used }\end{array}$ & $\begin{array}{l}\text { No difference for the time dedicated to sport at school or in competition. } \\
\text { No difference for the type of physical activity during free time (ball games } \\
\text { very present, but time dedicated to them > inT1D ( } 6.8 \mathrm{~h} / \text { week vs. } 4.6 \mathrm{~h} / \\
\text { week), in } q \text { or } \hat{\varnothing} \text {. } \\
\text { Total time spent in a week for physical activity > in T1D. }\end{array}$ \\
\hline [107] & $\begin{array}{l}\text { Children and adolescent } \\
<18 \text { yo }\end{array}$ & No & $\begin{array}{l}\text { Descriptive questionnaire. Not } \\
\text { quantitative filled out by parents }\end{array}$ & $\begin{array}{l}33 \% \text { are involved in } 3 \text { different physical activities or more in a week, } 31 \% \\
\text { in only one, and } 15 \% \text { are sedentary. }\end{array}$ \\
\hline [108] & $\begin{array}{l}\text { क } 12-19 \text { yo (Tanner } \\
\text { stage } 2 \text {-5) }\end{array}$ & Yes & Uniaxisaccelerometer & $\begin{array}{l}\text { T1D are less involved in physical activity }(464 \pm 123 \text { vs. } 523 \pm 138 \\
\left.\text { counts. } \min ^{-1} . j^{-1}, P=0.06\right) \text { and are more sedentary }(443 \pm 60 \text { vs. } 390 \pm 73 \\
\left.\text { min. } j^{-1}, P<0.005\right) \text { vs. healthy. }\end{array}$ \\
\hline [90] & $\begin{array}{l}\mathrm{N}=17 \text { prepubescent; } \\
8.5-13 \text { yo }\end{array}$ & Yes & Questionnaire & $\begin{array}{l}\text { No quantitative difference of weekly physical activity (gym, leisure, } \\
\text { school) between T1D and healthy. }\end{array}$ \\
\hline [27] & $\mathrm{N}=23251 ; 3-18$ yo & No & $\begin{array}{l}\text { Questionnaire about physical activity } \\
\text { (> 30min) frequence a week }\end{array}$ & $\begin{array}{l}\text { Physical activity frequency in a week represented } 0 \text { to } 9 \text { times } / \text { week } \\
44.7 \% \text { of patients are inactive, } 37 \% \text { are involved } 1-2 \text { times/week, and } \\
18.3 \%>3 \text { times/week. } \\
\text { Increased frequency in older subjects, and in } ð \text { compared to } q\end{array}$ \\
\hline [35] & $\begin{array}{l}\mathrm{N}=138 \text { children and } \\
\text { adolescents }(5.9-20 \text { yo) }\end{array}$ & Yes & Questionnaire & $\begin{array}{l}\text { Physical activity score in moderate and high intensity }<\text { in T1D vs. healthy } \\
\text { Level and frequency of physical activity in moderate to high intensity, } \\
\text { frequency of PA < in } q \text { vs. } \hat{\alpha}\end{array}$ \\
\hline [29] & $\mathrm{N}=2269 ; 11-18$ yo & No & Questionnaire & Older patients and $q$ have less physical activity. \\
\hline [109] & $\begin{array}{l}\mathrm{N}=240 \text { children } 6-10 \\
\text { yo and } 483 \mathrm{~T} 1 \mathrm{D} \\
\text { adolescents from } 11 \text { to } \\
19 \text { yo }\end{array}$ & No & Questionnaire & $\begin{array}{l}54 \% \text { of patients don't follow recommendations of } 60 \mathrm{~min} / \text { day of moderate } \\
\text { to high intensity physical activity. } \\
+ \text { less active than } \delta \text { during childhood and adolescence }\end{array}$ \\
\hline [110] & $\begin{array}{l}\mathrm{N}=37 \text { children and } \\
\text { adolescents }\end{array}$ & No & HR recordings & $\begin{array}{l}\text { Moderate to high intensity cumulated physical activity = } 53.6 \mathrm{~min} / \text { day in } \\
\text { average (< recommendations of } 60 \mathrm{~min} / \text { day }) \\
\text { Only a few high intensity physical activity }(8.3 \mathrm{~min} / \text { day in average }) \\
\text { Physical activities are mostly } \leq 5 \mathrm{~min}\end{array}$ \\
\hline [37] & $N=32 ; 6-17$ yo & Yes & Accelerometer & $\begin{array}{l}\text { Total amount of physical activity (Counts) at moderate to high intensity }< \\
\text { in T1D vs. healthy }\end{array}$ \\
\hline [32] & $\mathrm{N}=203$ q $11-19$ yo & No & Questionnaire & $\begin{array}{l}\text { Physical activity for at least } 60 \mathrm{~min} / \text { day for only } 2.7 \text { days in average during } \\
\text { the last week, and } 3.1 \text { days in average during an usual week. }\end{array}$ \\
\hline [111] & $\mathrm{N}=384 ; 10-20$ yo & $\begin{array}{l}\text { Yes (healthy } \\
\text { and T2D) }\end{array}$ & $\begin{array}{l}\text { Week-to-a-page diary of physical activity } \\
\text { and electronic monitoring over } 3 \text { days } \\
\text { (report of sessions }>30 \text { min of physical } \\
\text { activity) }\end{array}$ & $\begin{array}{l}\text { No difference (slight decrease) of physical activity between T1D and } \\
\text { healthy. } \\
60 \% \text { (in average) of T1D have }<1 \text { session of } 30 \mathrm{~min} \text { of high intensity } \\
\text { physical activity /day and } 20 \% \text { have }<2 \text { sessions of moderate to high } \\
\text { intensity /day (whereas international recommendations are } 2 \text { sessions of } \\
\text { moderate to high intensity of physical activity a day). }\end{array}$ \\
\hline [112] & $\mathrm{N}=48 ; 5-18$ ans & Yes & Accelerometer & $\begin{array}{l}\text { Total physical activity decreased in T1D vs. healthy. } \\
\text { Only } 38.5 \% \text { of T1D and } 60.4 \% \text { of healthy matched recommendations of } \\
60 \text { min/day of moderate to high intensity physical activity. }\end{array}$ \\
\hline [113] & $\mathrm{N}=129$; children & Yes & Questionnaire by phone & $\begin{array}{l}\text { Physical activity comparable between T1D and healthy. } \\
\text { T1D more involved in team sport. }\end{array}$ \\
\hline [31] & $\begin{array}{l}\mathrm{N}=19 \text { o } ;<18.5 \text { yo; } \\
\text { Tanner stages } 4-5\end{array}$ & Yes & Questionnaire & $\begin{array}{l}\text { Tendancy (NS) for a lower physical activity in gym in T1D }(0.7 \mathrm{~h} / \text { week in } \\
\text { average) vs. healthy ( } 1.4 \mathrm{~h} / \text { week in average). }\end{array}$ \\
\hline [34] & $\mathrm{N}=60 ; 8-16$ yo & Yes & Accelerometer & No difference in physical activity nor intensity between T1D and healthy. \\
\hline [72] & $\mathrm{N}=24$ children $<7$ yo & Yes & Accelerometer and HR recording & $\begin{array}{l}\text { T1D less active than healthy, present } 16 \mathrm{~min} \text { less in moderate to high } \\
\text { intensity physical activity. } \\
\text { Total physical activity (counts/day and } \min / \text { day) and time spent in } \\
\text { moderate to high intensity physical activity }<\text { in } q \text { vs. } \delta .\end{array}$ \\
\hline [98] & $\begin{array}{l}\mathrm{N}=35 \text { children } \\
\text { prepubescent/peri- } \\
\text { pubescent }\end{array}$ & Yes & Accelerometer and questionnaire & $\begin{array}{l}\text { Total physical activity measured with accelerometer < in T1D vs. healthy } \\
\text { whereas physical activity estimated with questionnaire comparable in } \\
\text { both groups. }\end{array}$ \\
\hline [91] & $\mathrm{N}=106 ; 8-18$ yo & Yes & Questionnaire & No difference between T1D and healthy. \\
\hline
\end{tabular}

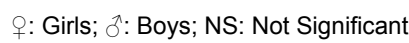

Table 2: Physical activity level in young T1D. 
Citation: Leclair E, de Kerdanet M, Riddell M, Heyman E (2013) Type 1 Diabetes and Physical Activity in Children and Adolescents. J Diabetes Metab S10: 004. doi:10.4172/2155-6156.S10-004

Page 5 of 10

\begin{tabular}{|c|c|c|c|c|c|c|c|}
\hline Authors & $\begin{array}{l}\text { T1D subjects } \\
\text { included }\end{array}$ & \multicolumn{2}{|c|}{ Exercise description } & \multicolumn{2}{|c|}{$\begin{array}{l}\text { Exercise time } \\
\text { (vs. meal \& insulin) }\end{array}$} & $\begin{array}{l}\text { Glucose evolution during } \\
\text { exercise }\end{array}$ & $\begin{array}{l}\text { Glucose evolution during } \\
\text { recovery }\end{array}$ \\
\hline \multicolumn{8}{|c|}{ Maximal graded exercise } \\
\hline \multicolumn{8}{|c|}{ Continuous moderate intensity exercise } \\
\hline [77] & $\begin{array}{l}\mathrm{N}=10 ; 10-19 \text { yo } \\
\text { Age : } 15.7 \pm 3 \\
\text { years } \\
\text { HbA1c }:<10 \% \\
\text { With insulin pump }\end{array}$ & \multicolumn{2}{|c|}{$\begin{array}{l}\text { Continuous moderate intensity exercise, } 40 \\
\text { to } 45 \text { min at } 60 \% \mathrm{VO}_{2} \text { max on ergocycle } \\
2 \text { exercise conditions, in randomized order, } \\
\text { staggered by } 7 \text { days : with basal insulin rate } \\
\text { reduced by } 50 \% \text { with the pump suspended } \\
\text { basal. } \\
\text { Back to normal basal rate } 5 \mathrm{~min} \text { after } \\
\text { exercise } \\
\text { No physical activity in the previous } 24 \mathrm{~h}\end{array}$} & \multicolumn{2}{|c|}{$\begin{array}{l}2 \mathrm{~h} \text { after standardized } \\
\text { breakfast and usual insulin } \\
\text { bolus, not reduced (in order } \\
\text { to mimic conditions of an } \\
\text { unplaned exercise) } \\
\text { Glucide intake }(20 \mathrm{~g} \text { ) before } \\
\text { exercise and } 15 \mathrm{~min} \text { after } \\
\text { exercise. } \\
\text { Glycemia before exercise } \\
\text { between } 1 \text { and } 3 \mathrm{~g} / \mathrm{L} \text {, with no } \\
\text { ketosis }\end{array}$} & $\begin{array}{l}\downarrow \text { glycemia in average of } \\
29 \% \text { ( } 2 \text { hypoglycemia i.e. } \\
<70 \mathrm{mg} / \mathrm{dL} \text { ) and } 35.5 \% \text { ( } 2 \\
\text { hypoglycemia) for exercise } \\
\text { with } 50 \% \text { basal rate, and } \\
\text { exercise with suspended } \\
\text { basal rate (no significant } \\
\text { difference between both } \\
\text { conditions) (and no significant } \\
\text { difference in cortisol, GH, NE) } \\
\text { Insulin concentration } \uparrow \text { at the } \\
\text { beginning of exercise (until } \\
20 \text { min) then } \downarrow \text { back to initial } \\
\text { values at the end of exercise, } \\
\text { and continues to } \downarrow \text { until } 45 \text { min } \\
\text { recovery (no significant } \\
\text { difference between both } \\
\text { conditions) } \\
\text { Subjects with hypoglycemia } \\
\text { during exercise started it with } \\
<\text { glycemia level and }>\text { insulin } \\
\text { concentration vs. other } \\
\text { subjects }\end{array}$ & $\begin{array}{l}\text { Glycemia goes back to initial } \\
\text { values after } 45 \text { min recovery } \\
\text { Data from continuous glucose } \\
\text { sensor: } \\
\text { Every subject had } 1 \text { to } 3 \\
\text { delayed hypoglycemia } 1 \mathrm{~h} \text { after } \\
\text { each exercise (after } 2.5 \mathrm{~h} \text { to } \\
12 \mathrm{~h} \text { ), not always symptomatic. } \\
9 \text { and } 6 \text { delayed hypoglycemia } \\
\text { after } 50 \% \text { basal rate and } \\
\text { suspended basal rate } \\
\text { respectively (no difference) } \\
\end{array}$ \\
\hline [114] & $\mathrm{N}=50 ; 11-17$ yо & \multirow[t]{4}{*}{$\begin{array}{l}\text { Exercise : } 4 \\
\text { sessions of } 15 \\
\text { min exercise } \\
\text { on treadmill at } \\
140 \text { bpm, with } \\
5 \text { min recovery in } \\
\text { between }(140 \mathrm{bpm} \\
\approx 55 \% \mathrm{VO}_{2} \text { max) }\end{array}$} & $\begin{array}{l}\text { Comparison between } \\
\text { a sedentary and } \\
\text { exercising day } \\
\text { staggered by } 1 \text { to } 4 \\
\text { weeks in randomized } \\
\text { order (with meal and } \\
\text { same insulin dose) }\end{array}$ & \multirow[t]{2}{*}{$\begin{array}{l}\text { Exercise at } \\
4 \mathrm{pm}-5 \mathrm{pm} \\
\text { Same } \\
\text { insulin } \\
\text { treatment } \\
\text { as usual }\end{array}$} & $\begin{array}{l}\text { Glycemia } \\
\text { before exercise } \\
\text { between } 1 \text { and } \\
2 \mathrm{~g} / \mathrm{L} \\
\text { If glycemia< } \\
0.60 \mathrm{~g} / \mathrm{L} \text { during } \\
\text { exercise or } \\
\text { during the night } \\
\rightarrow \text { glucide intake }\end{array}$ & $\begin{array}{l}22 \% \text { of patients had a } \\
\text { hypoglycemic episode }\end{array}$ & $\begin{array}{l}\text { Averaged glycemia from } 10 \mathrm{pm} \\
\text { to } 6 \text { am < after the afternoon } \\
\text { with exercise vs. sedentary } \\
\text { Nocturnal hypoglycemia } \\
\text { occurrence frequency }>\text { the } \\
\text { next night after exercise vs. } \\
\text { sedentary } \\
\text { No nocturnal hypoglycemia the } \\
\text { sedentary day when glycemia } \\
\text { before bedtime }>1.30 \mathrm{~g} / \mathrm{L} \\
\text { No significant difference } \\
\text { related to counterregulatory } \\
\text { hormones (GH, E, NE, } \\
\text { Cortisol, Glucagon) during } \\
\text { the night after exercise vs. } \\
\text { sedentary }\end{array}$ \\
\hline [75] & $\begin{array}{l}\mathrm{N}=49 ; 8-17 \text { yo } \\
\text { with insulin pump }\end{array}$ & & $\begin{array}{l}2 \text { days of exercise } \\
\text { including one with } \\
\text { suspended insulin } \\
\text { basal rate during } \\
\text { exercise and the } \\
45 \text { min recovery, } \\
\text { staggered by } 6 \text { to } \\
36 \text { days in randomized } \\
\text { order (with the same } \\
\text { meal) }\end{array}$ & & $\begin{array}{l}\text { Glycemia } \\
\text { before exercise } \\
\text { between } 1.2 \\
\text { and } 2 \mathrm{~g} / \mathrm{L}\end{array}$ & $\begin{array}{l}\text { Hypoglycemia }(<0.7 \mathrm{~g} / \mathrm{L}) \\
\text { during exercise are less } \\
\text { frequent when basal insulin } \\
\text { rate is suspended ( } 16 \% \text { vs. } \\
43 \%) \\
\downarrow \text { glycemia during exercise }< \\
\text { when basal rate suspended } \\
(-28 \% \text { vs }-41 \%)\end{array}$ & $\begin{array}{l}\text { After } 45 \mathrm{~min} \text { of recovery : } \\
\text { Hyperglycemia ( } \uparrow 20 \% \\
\text { compared to value at the end } \\
\text { of exercise, or }>2 \mathrm{~g} / \mathrm{L}) \text { more } \\
\text { frequent when insulin basal } \\
\text { rate is suspended }(27 \% \text { vs. } \\
4 \%) \\
\text { No abnormal ketonemia }\end{array}$ \\
\hline [116] & $\begin{array}{l}\mathrm{N}=10 \text { adolescents; } \\
15.2 \text { yo in } \\
\text { average } ; 6.9 \% \\
\text { HbA1c in average }\end{array}$ & & & \multicolumn{2}{|c|}{$\begin{array}{l}\text { Exercise at around } 3 \mathrm{pm} \\
\text { Basal insulin rate maintained } \\
\text { during exercise }\end{array}$} & $\begin{array}{l}\text { Averaged glycemia before } \\
\text { exercise : } 1.62 \mathrm{~g} / \mathrm{L} \\
\text { Glycemia } \downarrow \text { by } 52 \% \text { in } \\
\text { average during exercise }\end{array}$ & \\
\hline [76] & $\begin{array}{l}\mathrm{N}=16 ; 10-17 \text { yo } \\
\mathrm{HbA} 1 \mathrm{c}<10 \% ; \\
\text { average }=7.5 \% ; \\
\text { with insulin pump }\end{array}$ & & $\begin{array}{l}3 \text { conditions } \\
\text { (randomized order): } \\
2.5 \mathrm{mg} \text { oral Terbutaline } \\
\text { at bedtime } ; 20 \% \text { basal } \\
\text { insulin rate reduction } \\
\text {; no modification } \\
\text { of usual treatment } \\
\text { (=control) } \\
\text { Staggered by at least } \\
72 \mathrm{~h}\end{array}$ & \multicolumn{2}{|c|}{$\begin{array}{l}\text { Standardized lunch and } \\
\text { normal insulin bolus } \\
\text { Exercise at } 4 \mathrm{pm} \text { (glycemia } \\
\text { before exercise between } 1.2 \\
\text { and } 2 \mathrm{~g} / \mathrm{L} \text { ) } \\
\text { Suspended basal insulin } \\
\text { rate during exercise then } \\
\text { decreased by } 50 \% \text { during the } \\
\text { next } 45 \mathrm{~min} \text { after exercise } \\
\text { Glucide snack if glycemia< } \\
0.7 \mathrm{~g} / \mathrm{L} \text { during the } 5 \text { min } \\
\text { recovery periods and during } \\
\text { the following recovery }\end{array}$} & & $\begin{array}{l}\text { Averaged glycemia at } \\
\text { midnight : } 1.88 \mathrm{~g} / \mathrm{L} \text { after } \\
\text { terbutaline } ; 1.72 \mathrm{~g} / \mathrm{L} \text { after basal } \\
\text { insulin reduction }<\text { vs. } 1.27 \mathrm{~g} / \mathrm{L} \\
\text { control } \\
\text { Terbutaline : No more } \\
\text { nocturnal hypoglycemia but } \\
\text { more frequent hyperglycemia } \\
>2.5 \mathrm{~g} / \mathrm{L} \text { vs. control } \\
\text { Basal insulin rate decrease : } \\
\text { less glycemia }<0.8 \text { and } 0.7 \mathrm{~g} / \mathrm{L} \\
\text { but more }>2.5 \mathrm{~g} / \mathrm{L} \text { vs. control }\end{array}$ \\
\hline
\end{tabular}


Citation: Leclair E, de Kerdanet M, Riddell M, Heyman E (2013) Type 1 Diabetes and Physical Activity in Children and Adolescents. J Diabetes Metab S10: 004. doi:10.4172/2155-6156.S10-004

\begin{tabular}{|c|c|c|c|c|c|}
\hline$[117]$ & $\begin{array}{l}\mathrm{N}=9 ; 16 \text { yo in } \\
\text { average ; average } \\
\mathrm{HbA}_{1 \mathrm{c}} 7.8 \%\end{array}$ & $\begin{array}{l}1 \text { exercise day ( } 45 \mathrm{~min} \text { at } 95 \% \text { of second } \\
\text { lactic threshold }=54.9 \pm 2.8 \% \mathrm{VO}_{2} \text { peak on } \\
\text { ergocycle) and } 1 \text { sedentary day, staggered } \\
\text { by } 4 \text { weeks, in a randomized order }\end{array}$ & $\begin{array}{l}\text { Exercise at } 4 \mathrm{pm} \\
\text { Morning : usual breakfast } \\
\text { and usual rapid acting insulin } \\
\text { injection, but no intermediate/ } \\
\text { long acting. } \\
\text { From } 11 \mathrm{am} \text { : iv insulin } \\
\text { infusion at an usual basal } \\
\text { rate (=50\% of total insulin } \\
\text { dose /day) } \\
\text { At noon : standardized meal } \\
+ \text { usual insulin bolus } \\
\text { Comparable insulin } \\
\text { concentration between both } \\
\text { days } \\
\text { Comparable previous } 24 \mathrm{~h} \\
\text { diet } \\
48 \mathrm{~h} \text { before : no } \\
\text { hypoglycemia ; } 24 \mathrm{~h} \text { before : } \\
\text { no exercise } \\
\text { \% : in the middle of } \\
\text { menstrual cycle follicular } \\
\text { phase }\end{array}$ & $\begin{array}{l}\text { iv infused glucose in order to } \\
\text { maintain euglycemia (during } \\
18 \mathrm{~h} \text { ) : glucose infusion rate in } \\
\text { order to maintain glycemia> } \\
\text { during exercise }\end{array}$ & $\begin{array}{l}\text { Glucose infusion rate in order } \\
\text { to maintain glycemia > at the } \\
\text { beginning of recovery after } \\
\text { exercise (90min recovery) } \\
\text { and again } 7-11 \mathrm{~h} \text { after } \\
\text { exercise (=early or delayed } \\
\text { hypoglycemia risk) } \\
\text { No difference in } \\
\text { counterregulatory hormones } \\
\text { level between exercise } \\
\text { and sedentary days except } \\
\text { during early recovery : } \\
\text { peaks E, NE, GH, Cortisol } \\
>\text { ( } \rightarrow \text { compromised } \\
\text { nocturnal hypoglycemia } \\
\text { counterregulatory response } \\
\text { after exercise) }\end{array}$ \\
\hline \multicolumn{6}{|c|}{ High intensity intermittent exercise } \\
\hline [118] & $\begin{array}{l}\mathrm{N}=12 ; 12.2-15.8 \\
\text { yo } ; \text { Tanner stages } \\
2-4 ; \mathrm{HbA} 1 \mathrm{c} 6.5- \\
10.5 \%\end{array}$ & $\begin{array}{l}10 \text { bouts of } 2 \mathrm{~min} \text { at } 80 \% \mathrm{VO}_{2} \text { peak with } \\
1 \text { minute recovery between each (on } \\
\text { ergocycle) }\end{array}$ & $\begin{array}{l}\text { In the norning, after light } \\
\text { breakfast } \\
\text { Glycemia maintained } \\
\text { between } 0.9 \text { and } 1.10 \mathrm{~g} / \mathrm{L} \\
\text { during } 90 \mathrm{~min} \text { before exercise } \\
\text { by infusing insulin (clamp) } \\
\text { then insulin rate infusion } \\
\text { maintained at the same level } \\
\text { during exercise. }\end{array}$ & $\begin{array}{l}\text { Glucose iv infusion in order to } \\
\text { maintain euglycemia during } \\
\text { exercise : average infusion } \\
\text { rate }=1.5 \mathrm{mg} / \mathrm{kg} / \mathrm{min} \text { for } 90 \\
\mathrm{~min} \text { before exercise, } 1.7 \mathrm{mg} / \\
\mathrm{kg} / \mathrm{min} \text { at the end of exercise, } \\
\text { and } 1.7 \mathrm{mg} / \mathrm{kg} / \mathrm{min} \text { after } \\
30 \mathrm{~min} \text { recovery }\end{array}$ & \\
\hline \multicolumn{6}{|c|}{ Moderate intensity continuous vs. High intensity intermittent exercise } \\
\hline \multirow[t]{3}{*}{ [86] } & \multirow{3}{*}{$\begin{array}{l}\mathrm{N}=12 ; \\
14-19 \text { yo, Tanner } \\
\text { stages } 4-5 ;(+ \\
\left.\text { and }{ }^{\pi}\right) \\
\mathrm{HbA}_{1 \mathrm{c}} 6.6-9.6 \% \\
\text { Actives }_{2} \\
2 \text { adolescents } \\
\text { excluded from the } \\
\text { analysis because } \\
\text { of a nocturnal } \\
\text { hypoglycemia } \\
\text { the night before } \\
\text { continuous } \\
\text { exercise }\end{array}$} & Maximal graded test on ergocycle & \multirow{3}{*}{$\begin{array}{l}2 \mathrm{~h} \text { in average after breakfast } \\
\text { Insulin dose according to } \\
\text { subject's habits } \\
3 \text { exercises performed on } 3 \\
\text { consecutive days, always in } \\
\text { the same order : graded test, } \\
\text { continuous, and intermittent }\end{array}$} & $\begin{array}{l}\downarrow \text { glycemia }(-1,5 \mathrm{mM} \text { in } \\
\text { average) (final value }=11.2 \\
\mathrm{mM} \text { in average) } \\
\text { No hypoglycemic episode } \\
\uparrow \uparrow \mathrm{E}\left({ }^{*} 10\right) \text { and } \mathrm{NE}\left({ }^{*} 8\right)\end{array}$ & \\
\hline & & $\begin{array}{l}\text { Continuous } 60 \mathrm{~min} \text { at } 40 \% \text { of } \mathrm{VO}_{2} \text { max on } \\
\text { ergocyle }\end{array}$ & & $\begin{array}{l}\downarrow \downarrow \text { glycemia }(-4,1 \mathrm{mM} \text { in } \\
\text { average) (final value }=11.2 \\
\mathrm{mM} \text { in average) } \\
\text { No hypoglycemic episode } \\
\uparrow \mathrm{E}\left({ }^{*} 5\right) \text { et } \mathrm{NE}\left({ }^{*} 3\right)\end{array}$ & \\
\hline & & $\begin{array}{l}\text { Intermittent exercise on ergocycle : } 5 \mathrm{~min} \\
\text { warm-up, and } 6 \text { times } 3 \mathrm{~min} \text { at } 70 \% \text { of } \\
\mathrm{VO}_{2} \text { max interspersed with } 1.5 \mathrm{~min} \text { active } \\
\text { recovery (light resistance cycling), and } 5 \\
\text { min resting time }\end{array}$ & & $\begin{array}{l}\downarrow \text { glycemia }(-2.7 \mathrm{mM} \text { in } \\
\text { average) (final value }=11.4 \\
\mathrm{mM} \text { in average) } \\
\text { No hypoglycemic episode } \\
\uparrow \uparrow E\left({ }^{*} 8\right) \text { and } \mathrm{NE}\left({ }^{*} 7\right) \\
\uparrow \text { more important for cortisol } \\
\text { vs. Other exercises }\end{array}$ & \\
\hline \multicolumn{6}{|c|}{ Everyday life exercises } \\
\hline [119] & $\begin{array}{l}n=30 ; 12-18 \text { yo; } \\
\mathrm{HbA} 1 c<12 \%\end{array}$ & $\begin{array}{l}\text { Parallel between accelerometer data } \\
\text { and continuous intersticial glucose } \\
\text { concentration measurement (subcutaneous } \\
\text { sensor) }\end{array}$ & & $\begin{array}{l}\text { Hyperglycemia rebound after } \\
\text { exercise induced glycemia } \\
\text { decrease. } \\
\text { Hypothesis: This rebound } \\
\text { could be linked to : SNS } \\
\text { effect during physical } \\
\text { activity, a strategy before } \\
\text { physical activity in order to } \\
\text { prevent exercise induced } \\
\text { hypoglycemia, or an } \\
\text { excessive treatment for low } \\
\text { glycemia. }\end{array}$ & \\
\hline
\end{tabular}

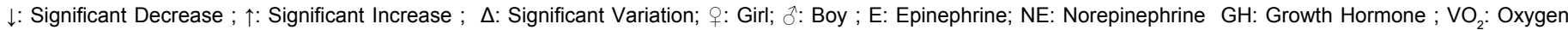
Comsumption; HbA1c: A1 Glycated Hemoglobin ; NS: Not Significant

In blue: studies about the effect of insulin dose variation on exercise glycemia; In green: results about the effect of glycemia variation on performance; in orange: associated hormones response

Table 3: Evolution of blood and plasma glucose concentration in T1D according to different exercise type. 
It is important to note that hypoglycemia is not the only concern with exercise for patients with T1D. Indeed, hyperglycemia can occur, particularly if blood insulin levels are insufficient during the activity, or if very high intensity exercise is performed $[82,92,93]$.

Physical fitness impairment in young T1D: It has recently been shown in 304 young T1D that physical activity level and self-perceived physical fitness are significantly related [94]. In addition, literature suggests that aerobic fitness (measured or estimated with maximal incremental test or submaximal test respectively) decreases with age in young T1D. So in T1D prepubescent boys, aerobic fitness is reported to be preserved $[95,96]$ whereas it might already be declined in girls at the same age [96].

In adolescents, aerobic fitness is often impaired in boys [19,9699] and girls [96,98-100] compared to healthy peers. This impairment in aerobic fitness is even more pronounced when diabetes control is poor [39,50,96,97,101-103]. Only 3 studies [21,50,91] have shown that physical fitness is normal in T1D adolescents, perhaps because physical activity levels were also high. Also, T1D girls presented lower values compared to T1D boys, but this gender difference was not observed in healthy adolescents [50]. This deterioration in the fitness of girls could partly be explained by the fat mass gain that occurs during puberty $[37,104,121-125]$

\section{Conclusion}

Physical activity is challenging for the child with T1D. The child and his or her family member, teacher, coach and friends need to be aware of the basic strategies to prevent hypoglycemia and maintain reasonable glucose control. Initial glycemia, time of the last rapid acting insulin injection, injection site, diet, time of the day, exercise type, etc... are all factors to be considered in order to anticipate the hypoglycemic or hyperglycemic effect of exercise (Figure 2). Moreover, the individual response to exercise can be different for each patient and sometimes even within a patient, thus making general recommendations around exercise and blood glucose management strategies is difficult. Therefore, it would be interesting in future investigations to study different individualized responses to exercise, while taking into consideration the previously shown parameters that are established to influence glucose control. Thus, it could be possible to better anticipate glycemic variations during exercise and recovery. These tests could be taken into consideration in the patient's therapeutic approach.

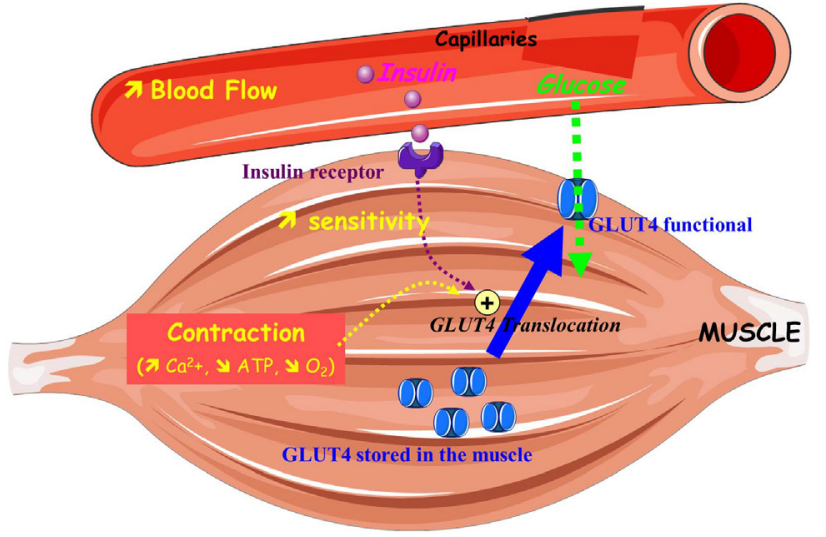

Figure 1: Physiological mechanisms of hypoglycemia during exercise.

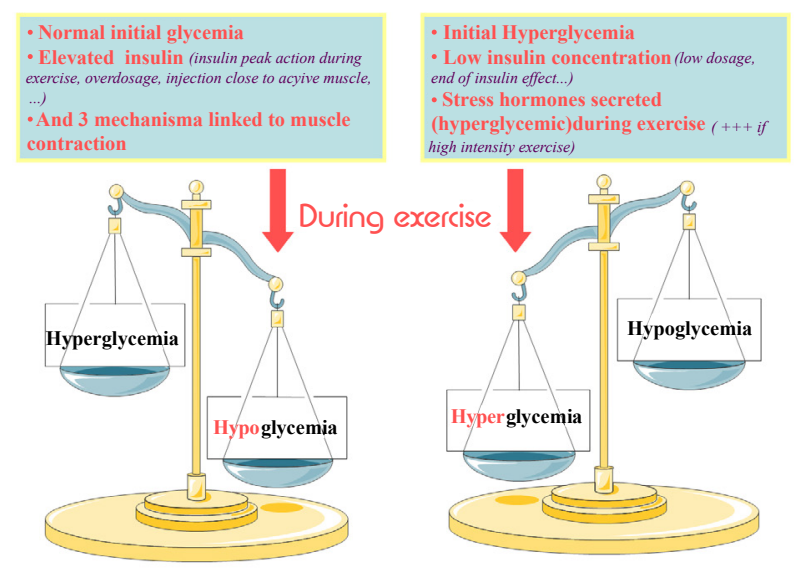

Figure 2: Hypoglycemic or hyperglycemic effect during exercise?

Glycemic variations during exercise do not mean that regular exercise is not beneficial. Indeed after each exercise session, insulin receptor sensitivity improves. Moreover, regular exercise allows for the continued increase muscle mass, and muscle tissue is the single greatest "consumer" of glucose, even at rest. So physical activity, through muscle mass increase can contribute to improve glycemic control. Moreover, exercise clearly offers many health and psychological benefits. Unfortunately, T1D patients do not seem to be involved enough in exercising to reach the daily recommendations. Further studies would help to specify the barriers to physical activity, especially in young T1D girls. This information could be useful to help young patients and their families with improved self-management programs.

\section{References}

1. Riddell MC, Iscoe KE (2006) Physical activity, sport, and pediatric diabetes Pediatr Diabetes 7: 60-70.

2. Wolfe RR (1998) Metabolic interactions between glucose and fatty acids in humans. Am J Clin Nutr 67: 519S-526S.

3. Giannini C, de Giorgis T, Mohn A, Chiarelli F (2007) Role of physical exercise in children and adolescents with diabetes mellitus. J Pediatr Endocrinol Metab 20: $173-184$

4. Toni S, Reali MF, Barni F, Lenzi L, Festini F (2006) Managing insulin therapy during exercise in type 1 diabetes mellitus. Acta Biomed 77 Suppl 1: 34-40.

5. Burr JF, Shephard RJ, Riddell MC (2012) Physical activity in type 1 diabetes mellitus: assessing risks for physical activity clearance and prescription. Can Fam Physician 58: 533-535.

6. Corigliano G, lazzetta N, Corigliano M, Strollo F (2006) Blood glucose changes in diabetic children and adolescents engaged in most common sports activities. Acta Biomed 77 Suppl 1: 26-33.

7. Gazurek D, Wójcik M, Szmigiel C, Dziatkowiak H, Gąsiorowska M (2011) Assessment of the influence of puberty on changes in post exercise glycaemia after variable intensity physical effort in children and adolescents with diabetes mellitus type 1 (DM1). Pediatr Endocrinol Diabetes Metab 17: 188-194.

8. Tonoli C, Heyman E, Roelands B, Buyse L, Cheung SS, et al. (2012) Effects of different types of acute and chronic (training) exercise on glycaemic control in type 1 diabetes mellitus: a meta-analysis. Sports Med 42: 1059-1080.

9. Kennedy A, Nirantharakumar K, Chimen M, Pang TT, Hemming K, et al. (2013) Does exercise improve glycaemic control in type 1 diabetes? A systematic review and meta-analysis. PLoS One 8: e58861.

10. Heyman E, Toutain C, Delamarche P, Berthon P, Briard D, et al. (2007) Exercise training and cardiovascular risk factors in type 1 diabetic adolescent girls. Pediatr Exerc Sci 19: 408-419. 
11. Rowland TW, Swadba LA, Biggs DE, Burke EJ, Reiter EO (1985) Glycemic control with physical training in insulin-dependent diabetes mellitus. Am J Dis Child 139: 307-310.

12. Faulkner MS, Michaliszyn SF, Hepworth JT (2010) A personalized approach to exercise promotion in adolescents with type 1 diabetes. Pediatr Diabetes 11: $166-174$

13. D'hooge R, Hellinckx T, Van Laethem C, Stegen S, De Schepper J, et al. (2011) Influence of combined aerobic and resistance training on metabolic control cardiovascular fitness and quality of life in adolescents with type 1 diabetes: a randomized controlled trial. Clin Rehabil 25: 349-359.

14. Seeger JP, Thijssen DH, Noordam K, Cranen ME, Hopman MT, et al. (2011) Exercise training improves physical fitness and vascular function in children with type 1 diabetes. Diabetes Obes Metab 13: 382-384.

15. Sideraviciute S, Gailiuniene A, Visagurskiene K, Vizbaraite D (2006) The effect of long-term swimming program on body composition, aerobic capacity and blood lipids in 14-19-year aged healthy girls and girls with type 1 diabetes mellitus. Medicina (Kaunas) 42: 661-666.

16. Michaliszyn SF, Faulkner MS (2010) Physical activity and sedentary behavior in adolescents with type 1 diabetes. Res Nurs Health 33: 441-449.

17. Huttunen NP, Länkelä SL, Knip M, Lautala P, Käär ML, et al. (1989) Effect of once-a-week training program on physical fitness and metabolic control in children with IDDM. Diabetes Care 12: 737-740.

18. Campaigne BN, Gilliam TB, Spencer ML, Lampman RM, Schork MA (1984) Effects of a physical activity program on metabolic control and cardiovascular fitness in children with insulin-dependent diabetes mellitus. Diabetes Care 7 $57-62$

19. larsson Y, Persson B, Sterky G, Thoren C (1964) Functional adaptation to rigorous training and exercise in diabetic and nondiabetic adolescents. J Appl Physiol 19: 629-635.

20. Marrero DG, Fremion AS, Golden MP (1988) Improving compliance with exercise in adolescents with insulin-dependent diabetes mellitus: results of a self-motivated home exercise program. Pediatrics 81: 519-525.

21. Mosher PE, Nash MS, Perry AC, LaPerriere AR, Goldberg RB (1998) Aerobic circuit exercise training: effect on adolescents with well-controlled insulindependent diabetes mellitus. Arch Phys Med Rehabil 79: 652-657.

22. Landt KW, Campaigne BN, James FW, Sperling MA (1985) Effects of exercise training on insulin sensitivity in adolescents with type I diabetes. Diabetes Care 8: 461-465.

23. Roberts L, Jones TW, Fournier PA (2002) Exercise training and glycemic control in adolescents with poorly controlled type 1 diabetes mellitus. J Pediatr Endocrinol Metab 15: 621-627.

24. Baevre H, Søvik O, Wisnes A, Heiervang E (1985) Metabolic responses to physical training in young insulin-dependent diabetics. Scand J Clin Lab Invest 45: $109-114$

25. Maggio AB, Rizzoli RR, Marchand LM, Ferrari S, Beghetti M, et al. (2012) Physical activity increases bone mineral density in children with type 1 diabetes. Med Sci Sports Exerc 44: 1206-1211.

26. Aouadi R, Khalifa R, Aouidet A, Ben Mansour A, Ben Rayana M, Mdini F, et al. (2011) Aerobic training programs and glycemic control in diabetic children in relation to exercise frequency. J Sports Med Phys Fitness 51: 393-400.

27. Torres-Tamayo M, Perez-Pasten LE, Barron-Uribe C, Hermida-Gutierrez I, Zamora-Gonzalez J, et al. (1998) Improved metabolic control does not change plasma lipoprotein(a) levels in adolescents with type 1 diabetes mellitus. Arch Med Res 29: 307-312.

28. Dahl-Jørgensen K, Meen HD, Hanssen KF, Aagenaes O (1980) The effect of exercise on diabetic control and hemoglobin $\mathrm{A} 1(\mathrm{HbA} 1)$ in children. Acta Paediatr Scand Suppl 283: 53-56.

29. Ruzic L, Sporis G, Matkovic BR (2008) High volume-low intensity exercise camp and glycemic control in diabetic children. J Paediatr Child Health 44 122-128.

30. Sideraviciute S, Gailiuniene A, Visagurskiene K, Vizbaraite D (2006) The effect of long-term swimming program on glycemia control in 14-19-year aged healthy girls and girls with type 1 diabetes mellitus. Medicina (Kaunas) 42: 513-518.

31. Woo J, Yeo NH, Shin KO, Lee HJ, Yoo J, et al. (2010) Antioxidant enzyme activities and DNA damage in children with type 1 diabetes mellitus after 12 weeks of exercise. Acta Paediatr 99: 1263-1268.
32. Sackey AH, Jefferson IG (1996) Physical activity and glycaemic control in children with diabetes mellitus. Diabet Med 13: 789-793.

33. Herbst A, Kordonouri O, Schwab KO, Schmidt F, Holl RW, et al. (2007) Impact of physical activity on cardiovascular risk factors in children with type 1 diabetes: a multicenter study of 23,251 patients. Diabetes Care 30: 2098-2100.

34. Chen SR, Lee YJ, Chiu HW, Jeng C (2008) Impact of physical activity on heart rate variability in children with type 1 diabetes. Childs Nerv Syst 24: 741-747.

35. Aman J, Skinner TC, de Beaufort CE, Swift PG, Aanstoot HJ, et al. (2009) Associations between physical activity, sedentary behavior, and glycemic control in a large cohort of adolescents with type 1 diabetes: the Hvidoere Study Group on Childhood Diabetes. Pediatr Diabetes 10: 234-239.

36. Herbst A, Bachran R, Kapellen T, Holl RW (2006) Effects of regular physical activity on control of glycemia in pediatric patients with type 1 diabetes mellitus. Arch Pediatr Adolesc Med 160: 573-577.

37. Heyman E, Berthon P, Youssef H, Delamarche A, Briard D, et al. (2012) Metabolic dysfunction in late-puberty adolescent girls with type 1 diabetes: relationship to physical activity and dietary intakes. Diabetes Metab 38: 337 342

38. Schweiger B, Klingensmith G, Snell-Bergeon JK (2010) Physical activity in adolescent females with type 1 diabetes. Int J Pediatr 2010: 328318.

39. Ludvigsson J (1980) Physical exercise in relation to degree of metabolic contro in juvenile diabetics. Acta Paediatr Scand Suppl 283: 45-49.

40. Cuenca-García M, Jago R, Shield JP, Burren CP (2012) How does physical activity and fitness influence glycaemic control in young people with Type 1 diabetes? Diabet Med 29: e369-376.

41. Valerio G, Spagnuolo MI, Lombardi F, Spadaro R, Siano M, et al. (2007) Physical activity and sports participation in children and adolescents with type 1 diabetes mellitus. Nutr Metab Cardiovasc Dis 17: 376-382.

42. Vanelli M, Corchia M, lovane B, Bernardini A, Mele A, et al. (2006) Selfmonitoring adherence to physical activity in children and adolescents with type 1 diabetes. Acta Biomed 77 Suppl 1: 47-50.

43. Trigona B, Aggoun Y, Maggio A, Martin XE, Marchand LM, et al. (2010) Preclinical noninvasive markers of atherosclerosis in children and adolescents with type 1 diabetes are influenced by physical activity. J Pediatr 157: 533-539.

44. Faulkner MS (2010) Cardiovascular fitness and quality of life in adolescents with type 1 or type 2 diabetes. J Spec Pediatr Nurs 15: 307-316.

45. Ramalho AC, de Lourdes Lima M, Nunes F, Cambuí Z, Barbosa C, et al. (2006) The effect of resistance versus aerobic training on metabolic control in patients with type-1 diabetes mellitus. Diabetes Res Clin Pract 72: 271-276.

46. Lithell H, Krotkiewski M, Kiens B, Wroblewski Z, Holm G, et al. (1985) Nonresponse of muscle capillary density and lipoprotein-lipase activity to regular training in diabetic patients. Diabetes Res 2: 17-21.

47. Wallberg-Henriksson H, Gunnarsson R, Henriksson J, DeFronzo R, Felig P, et al. (1982) Increased peripheral insulin sensitivity and muscle mitochondrial enzymes but unchanged blood glucose control in type I diabetics after physical training. Diabetes 31: 1044-1050.

48. Wallberg-Henriksson H, Gunnarsson R, Henriksson J, Ostman J, Wahren J (1984) Influence of physical training on formation of muscle capillaries in type diabetes. Diabetes 33: 851-857.

49. Amiel SA, Sherwin RS, Simonson DC, Lauritano AA, Tamborlane WV (1986) Impaired insulin action in puberty. A contributing factor to poor glycemic control in adolescents with diabetes. N Engl J Med 315: 215-219.

50. Arslanian S, Nixon PA, Becker D, Drash AL (1990) Impact of physical fitness and glycemic control on in vivo insulin action in adolescents with IDDM. Diabetes Care 13: 9-15.

51. Huber J, Fröhlich-Reiterer EE, Sudi K, Suppan E, Weinhandl G, et al. (2010) The influence of physical activity on ghrelin and IGF-1/IGFBP-3 levels in children and adolescents with type 1 diabetes mellitus. Pediatr Diabetes 11: 383-385.

52. Heymsfield SB, Gallagher D, Kotler DP, Wang Z, Allison DB, et al. (2002) Body-size dependence of resting energy expenditure can be attributed to nonenergetic homogeneity of fat-free mass. Am J Physiol Endocrinol Metab 282: E132-138.

53. Zurlo F, Larson K, Bogardus C, Ravussin E (1990) Skeletal muscle metabolism 
is a major determinant of resting energy expenditure. J Clin Invest 86: 14231427.

54. Abdul-Ghani MA, DeFronzo RA (2010) Pathogenesis of insulin resistance in skeletal muscle. J Biomed Biotechnol 2010: 476279.

55. Kiens B (2006) Skeletal muscle lipid metabolism in exercise and insulin resistance. Physiol Rev 86: 205-243.

56. Houmard JA (2008) Intramuscular lipid oxidation and obesity. Am J Physiol Regul Integr Comp Physiol 294: R1111-1116.

57. Strasser B, Arvandi M, Siebert U (2012) Resistance training, visceral obesity and inflammatory response: a review of the evidence. Obes Rev 13: 578-591.

58. Sell H, Eckel J, Dietze-Schroeder D (2006) Pathways leading to muscle insulin resistance--the muscle--fat connection. Arch Physiol Biochem 112: 105-113.

59. Marzolini S, Oh PI, Brooks D (2012) Effect of combined aerobic and resistance training versus aerobic training alone in individuals with coronary artery disease: a meta-analysis. Eur J Prev Cardiol 19: 81-94.

60. Sandvei M, Jeppesen PB, Støen L, Litleskare S, Johansen E, et al. (2012) Sprint interval running increases insulin sensitivity in young healthy subjects. Arch Physiol Biochem 118: 139-147.

61. Malatesta D, Werlen C, Bulfaro S, Chenevière X, Borrani $F(2009)$ Effect of high-intensity interval exercise on lipid oxidation during postexercise recovery. Med Sci Sports Exerc 41: 364-374.

62. Bailey RC, Olson J, Pepper SL, Porszasz J, Barstow TJ, et al. (1995) The level and tempo of children's physical activities: an observational study. Med Sci Sports Exerc 27: 1033-1041.

63. Robertson K, Adolfsson P, Riddell MC, Scheiner G, Hanas R (2008) Exercise in children and adolescents with diabetes. Pediatr Diabetes 9: 65-77.

64. Tunar M, Ozen S, Goksen D, Asar G, Bediz CS, et al. (2012) The effects of Pilates on metabolic control and physical performance in adolescents with type 1 diabetes mellitus. J Diabetes Complications 26: 348-351.

65. Wong CH, Chiang YC, Wai JP, Lo FS, Yeh CH, et al. (2011) Effects of a homebased aerobic exercise programme in children with type 1 diabetes mellitus. $J$ Clin Nurs 20: 681-691.

66. Zinman B, Zuniga-Guajardo S, Kelly D (1984) Comparison of the acute and long-term effects of exercise on glucose control in type I diabetes. Diabetes Care 7: 515-519.

67. Bernardini AL, Vanelli M, Chiari G, lovane B, Gelmetti C, et al. (2004) Adherence to physical activity in young people with type 1 diabetes. Acta Biomed 75: 153157.

68. Campaigne BN, Gunnarsson R (1988) The effects of physical training in people with insulin-dependent diabetes. Diabet Med 5: 429-433.

69. Wiltshire EJ, Hirte C, Couper JJ (2003) Dietary fats do not contribute to hyperlipidemia in children and adolescents with type 1 diabetes. Diabetes Care 26: $1356-1361$.

70. Strobl W, Widhalm K, Schober E, Frisch H, Pollak A, et al. (1985) Apolipoproteins and lipoproteins in children with type I diabetes: relation to glycosylated serum protein and HbA1. Acta Paediatr Scand 74: 966-971.

71. Erciyas F, Taneli F, Arslan B, Uslu Y (2004) Glycemic control, oxidative stress, and lipid profile in children with type 1 diabetes mellitus. Arch Med Res 35: 134-140.

72. Barta L, Czinner A, Tichy M, Bedö M (1986) Risk factors in childhood diabetes mellitus. Acta Paediatr Hung 27: 9-13.

73. Ingberg CM, Särnblad S, Palmér M, Schvarcz E, Berne C, et al. (2003) Body composition in adolescent girls with type 1 diabetes. Diabet Med 20: 10051011.

74. Martinez MT, Ramos O, Carretero N, Calvillan M, Gutierrez-Lopez MD, et al (1994) Lipoprotein (a) and other risk factors in children with insulin-dependent diabetes mellitus and children without diabetes. Diabete Metab 20: 522-525.

75. Goldberg RB (1981) Lipid disorders in diabetes. Diabetes Care 4: 561-572.

76. Kriska AM, LaPorte RE, Patrick SL, Kuller LH, Orchard TJ (1991) The association of physical activity and diabetic complications in individuals with insulin-dependent diabetes mellitus: the Epidemiology of Diabetes Complications Study--VII. J Clin Epidemiol 44: 1207-1214.
77. Sundberg F, Forsander G, Fasth A, Ekelund U (2012) Children younger than 7 years with type 1 diabetes are less physically active than healthy controls. Acta Paediatr 101: 1164-1169.

78. Mackey ER, Streisand R (2008) Brief report: The relationship of parental support and conflict to physical activity in preadolescents with type 1 diabetes. J Pediatr Psychol 33: 1137-1141.

79. Brazeau AS, Rabasa-Lhoret R, Strychar I, Mircescu H (2008) Barriers to physical activity among patients with type 1 diabetes. Diabetes Care 31: 21082109.

80. Diabetes Research in Children Network (DirecNet) Study Group, Tsalikian E, Kollman C, Tamborlane WB, Beck RW, et al. (2006) Prevention of hypoglycemia during exercise in children with type 1 diabetes by suspending basal insulin. Diabetes Care 29: 2200-2204.

81. Taplin CE, Cobry E, Messer L, McFann K, Chase HP, et al. (2010) Preventing post-exercise nocturnal hypoglycemia in children with type 1 diabetes. J Pediatr 157: 784-788.

82. Admon G, Weinstein Y, Falk B, Weintrob N, Benzaquen $H$, et al. (2005) Exercise with and without an insulin pump among children and adolescents with type 1 diabetes mellitus. Pediatrics 116: e348-355.

83. Heyman E, Briard D, Dekerdanet M, Gratas-Delamarche A, Delamarche P (2006) Accuracy of physical working capacity 170 to estimate aerobic fitness in prepubertal diabetic boys and in 2 insulin dose conditions. J Sports Med Phys Fitness 46: 315-321.

84. Peirce NS (1999) Diabetes and exercise. Br J Sports Med 33: 161-172.

85. Robertson K, Adolfsson P, Scheiner G, Hanas R, Riddell MC (2009) Exercise in children and adolescents with diabetes. Pediatr Diabetes 10 Suppl 12: 154 168

86. Yardley JE, Kenny GP, Perkins BA, Riddell MC, Malcolm J, et al. (2012) Effects of performing resistance exercise before versus after aerobic exercise on glycemia in type 1 diabetes. Diabetes Care 35: 669-675.

87. Guelfi KJ, Jones TW, Fournier PA (2005) The decline in blood glucose levels is less with intermittent high-intensity compared with moderate exercise in individuals with type 1 diabetes. Diabetes Care 28: 1289-1294.

88. Guelfi KJ, Ratnam N, Smythe GA, Jones TW, Fournier PA (2007) Effect of intermittent high-intensity compared with continuous moderate exercise on glucose production and utilization in individuals with type 1 diabetes. Am J Physiol Endocrinol Metab 292: E865-870.

89. Iscoe KE, Riddell MC (2011) Continuous moderate-intensity exercise with or without intermittent high-intensity work: effects on acute and late glycaemia in athletes with Type 1 diabetes mellitus. Diabet Med 28: 824-832.

90. Bussau VA, Ferreira LD, Jones TW, Fournier PA (2006) The 10-s maxima sprint: a novel approach to counter an exercise-mediated fall in glycemia in individuals with type 1 diabetes. Diabetes Care 29: 601-606.

91. Adolfsson P, Nilsson S, Albertsson-Wikland K, Lindblad B (2012) Hormona response during physical exercise of different intensities in adolescents with type 1 diabetes and healthy controls. Pediatr Diabetes 13: 587-596.

92. Brun JF, Marti B, Fédou C, Farré A, Renard E, et al. (2012) La baisse de la glycémie à l'exercice en plateau chez le diabétique insuliné est déterminée par la glycémie de départ et l'insulinémie. Sciences \& Sport 27( $\left.{ }^{\circ} 2\right)$ : 111-114.

93. Szmigiel C, Dziadkowiak H, Jesionek D, Gasiorowska M, Wojtas M, et al. (1996) [The influence of physical effort of variable intensity on glycemia in children with diabetes]. Pediatr Pol 71: 423-430.

94. O’Neill JR, Liese AD, McKeown RE, Cai B, Cuffe SP, et al. (2012) Physical activity and self-concept: the SEARCH for diabetes in youth case control study. Pediatr Exerc Sci 24: 577-588.

95. Heyman E, Briard D, Gratas-Delamarche A, Delamarche P, De Kerdanet (2005) Normal physical working capacity in prepubertal children with type 1 diabetes compared with healthy controls. Acta Paediatr 94: 1389-1394.

96. Lukács A, Mayer K, Juhász E, Varga B, Fodor B, et al. (2012) Reduced physical fitness in children and adolescents with type 1 diabetes. Pediatr Diabetes 13 432-437.

97. Poortmans JR, Saerens P, Edelman R, Vertongen F, Dorchy H (1986) Influence of the degree of metabolic control on physical fitness in type I diabetic adolescents. Int J Sports Med 7: 232-235.

98. Nordgren H, Freyschuss U, Persson B (1994) Blood pressure response 
Citation: Leclair E, de Kerdanet M, Riddell M, Heyman E (2013) Type 1 Diabetes and Physical Activity in Children and Adolescents. J Diabetes Metab S10: 004. doi:10.4172/2155-6156.S10-004

to physical exercise in healthy adolescents and adolescents with insulindependent diabetes mellitus. Clin Sci (Lond) 86: 425-432

99. Austin A, Warty V, Janosky J, Arslanian S (1993) The relationship of physical fitness to lipid and lipoprotein(a) levels in adolescents with IDDM. Diabetes Care 16: 421-425.

100. Gusso S, Hofman P, Lalande S, Cutfield W, Robinson E, et al. (2008) Impaired stroke volume and aerobic capacity in female adolescents with type 1 and type 2 diabetes mellitus. Diabetologia 51: 1317-1320.

101. Barkai L, Peja M, Vámosi I (1996) Physical work capacity in diabetic children and adolescents with and without cardiovascular autonomic dysfunction. Diabet Med 13: 254-258.

102. Williams BK, Guelfi KJ, Jones TW, Davis EA (2011) Lower cardiorespiratory fitness in children with Type 1 diabetes. Diabet Med 28: 1005-1007.

103. Fintini D, Di Giacinto B, Brufani C, Cafiero G, Patera PI, et al. (2012) Impaired energy expenditure despite normal cardiovascular capacity in children with type 1 diabetes. Horm Res Paediatr 78: 1-7.

104. Heyman E, Delamarche P, Berthon P, Meeusen R, Briard D, et al. (2007) Alteration in sympathoadrenergic activity at rest and during intense exercise despite normal aerobic fitness in late pubertal adolescent girls with type 1 diabetes. Diabetes Metab 33: 422-429.

105. Salem MA, Aboelasrar MA, Elbarbary NS, Elhilaly RA, Refaat YM (2010) Is exercise a therapeutic tool for improvement of cardiovascular risk factors in adolescents with type 1 diabetes mellitus? A randomised controlled trial. Diabetol Metab Syndr 2: 47.

106. larsson YA, Sterky GC, Ekengren KE, Moller TG (1962) Physical fitness and the influence of training in diabetic adolescent girls. Diabetes 11: 109-117.

107. sterky G, Larsson Y, Persson B (1963) Blood lipids in diabetic and non-diabetic schoolchildren. Acta Paediatr 52: 11-21.

108. Ludvigsson J, Larsson Y, Svensson PG (1980) Attitudes towards physical exercise in juvenile diabetics. Acta Paediatr Scand Suppl 283: 106-111.

109. Barta L, Molnár M, Madácsy L, Barta-Bedö M, Körner A (1983) The position of the diabetic child in society. Acta Paediatr Hung 24: 79-83.

110. Wieliczko MC, Gobert M, Mallet E (1991) [The participation in sports of diabetic children. A survey in the Rouen region]. Ann Pediatr (Paris) 38: 84-88.

111. Rowland TW, Martha PM Jr, Reiter EO, Cunningham LN (1992) The influence of diabetes mellitus on cardiovascular function in children and adolescents. In J Sports Med 13: 431-435

112. Raile K, Kapellen T, Schweiger A, Hunkert F, Nietzschmann U, et al. (1999) Physical activity and competitive sports in children and adolescents with type 1 diabetes. Diabetes Care 22: 1904-1905.
113. Lipman TH, Hayman LL, Fabian CV, DiFazio DA, Hale PM, et al. (2000) Risk factors for cardiovascular disease in children with Type I diabetes. Nurs Res 49: 160-166.

114. Särnblad S, Ekelund U, Aman J (2005) Physical activity and energy intake in adolescent girls with Type 1 diabetes. Diabet Med 22: 893-899.

115. Øverby NC, Margeirsdottir HD, Brunborg C, Anderssen SA, Andersen LF, et al. (2009) Physical activity and overweight in children and adolescents using intensified insulin treatment. Pediatr Diabetes 10: 135-141.

116. Edmunds S, Roche D, Stratton G (2010) Levels and patterns of physical activity in children and adolescents with type 1 diabetes and associated metabolic and physiologic health outcomes. J Phys Act Health 7: 68-77.

117. Lobelo F, Liese AD, Liu J, Mayer-Davis EJ, D'Agostino RB Jr, et al. (2010) Physical activity and electronic media use in the SEARCH for diabetes in youth case-control study. Pediatrics 125: e1364-1371.

118. Maggio AB, Hofer MF, Martin XE, Marchand LM, Beghetti M, et al. (2010) Reduced physical activity level and cardiorespiratory fitness in children with chronic diseases. Eur J Pediatr 169: 1187-1193.

119. Fainardi V, Scarabello C, Cangelosi A, Fanciullo L, Mastrorilli C, et al. (2011) Physical activity and sedentary lifestyle in children with type 1 diabetes: multicentre Italian study. Acta Biomed 82: 124-131.

120. Tsalikian E, Mauras N, Beck RW, Tamborlane WV, Janz KF, et al. (2005) Impact of exercise on overnight glycemic control in children with type 1 diabetes mellitus. J Pediatr 147: 528-534

121. Diabetes Research in Children Network (DirecNet) Study Group (2007) Impaired overnight counterregulatory hormone responses to spontaneous hypoglycemia in children with type 1 diabetes. Pediatr Diabetes 8: 199-205.

122. Mauras N, Xing D, Fox LA, Englert K, Darmaun D (2010) Effects of glutamine on glycemic control during and after exercise in adolescents with type 1 diabetes: a pilot study. Diabetes Care 33: 1951-1953.

23. McMahon SK, Ferreira LD, Ratnam N, Davey RJ, Youngs LM, et al. (2007) Glucose requirements to maintain euglycemia after moderate-intensity afternoon exercise in adolescents with type 1 diabetes are increased in a biphasic manner. J Clin Endocrinol Metab 92: 963-968.

124. Galassetti PR, Iwanaga K, Pontello AM, Zaldivar FP, Flores RL, et al. (2006) Effect of prior hyperglycemia on IL-6 responses to exercise in children with type 1 diabetes. Am J Physiol Endocrinol Metab 290: E833-839.

125. Maahs DM, Mayer-Davis E, Bishop FK, Wang L, Mangan M, et al. (2012) Outpatient assessment of determinants of glucose excursions in adolescents with type 1 diabetes: proof of concept. Diabetes Technol Ther 14: 658-664.
This article was originally published in a special issue, Diabetes \& Exercise handled by Editor(s). Dr. Lisa Stehno-Bittel, University of Kansas Medical Center, USA 